\title{
UUSIEN OPPIMISYMPÄRISTÖJEN PERUSTELUISTA
}

\author{
Uusien oppimisympäristöjen puolesta argumentoidaan monella \\ tavalla. Kommentoimme seuraavassa pilke silmäkulmassa \\ yleisimpiä argumentteja. Rajaamme tarkastelun koskemaan \\ suomenkielisiä julkaisuja, koska ne vaikuttavat eniten suomalaisiin \\ opettajiin, kouluihin ja oppilaitoksiin.
}

Uudella' oppimisympäristöllä tarkoitetaan yleensä virtuaalisia, moderneja, verkostopohjaisia ja avoimia oppimisympäristöjä. K yseisten oppimisympäristöjen luonnetta ja eroja ei sensijaan juurikaan kuvailla. Eräs paradoksi onkin, että uutta oppimisympäristöä on melko vaikea määritellä. Y leensä se on määritelty vertaamalla sitä vanhaan, minkä ongelmallisuutta pohdimme ensimmäiseksi. Tämän kritiikin tarkoituksena ei ole tyrmätä uusia oppimisympäristöjä, vaan syventää niiden ympärillä käytävää keskustelua ja pyrkiä löytämään entistä kestävämpiä perusteluja niiden tueksi.

Artikkelin eräänä motiivina ja jäsentäjänä toimii seuraava avoimen oppimisympäristön määritelmä:

"A vain oppimisympäristö on sellainen joustava formaali tai informaali oppimisympäristö, joka antaa opiskeijalle mahddlisuur den ja vapauden päättää opintojensa tavoitteista, opiskedun ajankohdasta, paikasta ja aikataulusta. Opiskdijalla tule dla jatkur va mahddlisuus kontrolloida oppimistaan ja saada siitä palautetta haluamassaan muodossa.“ (Pantzar \& V äliharju 1996, 26)

Määritelmän mukaan avoimet (tai uudet) oppi- misympäristöt ovat joustavia, itseohjautuvuuteen kannustavia tai ainakin sitä vaativia sekä ajasta ja paikasta riippumattomia. 0 ppimisen osalta uusien oppimisympäristöjen yhteydessä korostetaan lähes poikkeuksetta yhteistoiminnallisuutta ja konstruktiivista oppimiskäsitystä (esimerkiksi Lehtinen 1997). Pohdimme näitä teemoja seuraavassa lähemmin.

\section{Uusi ja vanha vastakkain}

U utta ja vanhaa oppimista ja oppimisympäristöä kuvataan usein dikotomisella taulukolla, jossa kahden mallin piirteet asetetaan vastakkain (ks. esimerkiksi Tella 1997, 56). Samalla tavalla on myyty andragogista lähestymistapaa mollaamalla vanhaa pedagogiaa (K nowles 1970), tutkimusmetodologioita ruttaamalla positivismia ja uusia pesuaineita vertaamalla niitä 'muihin johtaviin pesuainemerkkeihin'. Vaikka kahta mallia kuvattaisiin dimensioiden ääripäiksi, välittyy niistä kuva, että on kaksi vastakkaista mallia: uusi ja vanha. Ei ole epäselvää kumpi niistä on parempi, kun uuteen opiskeluympäristöön liitetään oppijan vastuu, aktiivisuus, konstruktiivisuus, avoimuus sekä sisäinen motivaatio ja kontrolli. O nko todellisuus näin vastakkainen? O vatko vanhat opiskeluym- 
päristöt todellakin tylsiä ja uudet dynaamisia, itseohjautuvia ja avoimia? Tuskin kukaan väittää näin olevan. Miksi sitten asiat esitetään vastakohtaisuuksien muodossa? Syy saattaa löytyä koko sosiaalisen elämän vastakohtaisuuksiin ja niiden argumentointiin perustuvasta luonteesta (Billig 1996). Asiat ja asenteet esitetään vastakohtaisuuksina, joita joko puolustetaan tai kritisoidaan, esimerkiksi pakolaisia, EU:a, tasaarvoa tai lasten kouluikää. Sosiaalisen elämän vastakohtaisuuksia sisältävä luonne ei saisi olla syynä siihen, että vastakohtaisuuksien kautta perustellaan koulutusjärjestelmän kehittämistä.

Vastakkainasetteluun liittyy tiedon hukkaamista. O n vaikea uskoa, että perinteisissä oppimisympäristöissä tapahtuva opiskelu olisi aina kontrolloitua, määräilevää ja opiskelijat olisivat passiivisia. E ivätkä uudet oppimisympäristöt välttämättä ole "hyviä". Hyvän oppimisen ja opiskeluympäristön taustalta löytyy monia tärkeitä asioita, jotka eivät näy opiskeluympäristöjen vastakkainasettelussa. O n myös muistettava, että opiskelu- tai oppimisympäristö on keino tavoitella jotain. Y leensä tämä tavoiteltava asia on oppiminen. O lennaisempaa kuin keinot, on se mitä opitaan, miksi opitaan ja miten oppimista voidaan hyödyntää. O ppimisen keinot ja välineet määräytyvät opiskelun tarkoituksen, tavoitteiden ja kohderyhmän pohjalta.

\section{Riippumattomuus ajasta ja paikasta}

Uusien oppimisympäristöjen yleisin perustelu lienee riippumattomuus ajasta ja paikasta. Perustelu löytyy joskus myös sellaisten oppimistilanteiden yhteydestä, jotka käytännössä sitovat opiskelijan videoneuvottelustudioon tai oppilaitoksen atk-luokkaan niiden aukioloaikoina. Ajan ja paikan luonne on kuitenkin varsin problemaattinen. Paikka tai tila on helppo määritellä fyysisenä ilmiönä, koska se on jokin aistein havaittava kokonaisuus. Toisaalta, miten havainnoistamme muodostuu tila tai paikka? Paikan ja tilan käsitteitä voidaan tarkentaa siten, että kun tilalle annetaan merkitys, siitä tu- lee paikka. Jokin tietty tila voidaan merkityksellistää olohuoneeksi, hissiksi tai kaupunginosaksi. Aika on tilaa ongelmallisempi, koska siitä ei voida tehdä objektiivisia havaintoja. K ellokin on vain sopimus, jolla mitataan aikaa, mutta se ei kerro mitä aika on. Mitä on siis aika ja miten siitä voidaan olla riippumattomia? O nko se mahdollista vain sellaisessa tilanteessa, jota kuvataan elokuvassa 'päiväni murmelina'; päähenkilö joutuu ilkeytensä takia elämään saman päivän aina samanlaisena uudelleen ja uudelleen vihaamassaan syrjäkylässä, eikä vapaudu loitsusta ennenkuin hoksaa käyttää loputtomat aikaresurssit hölmöilyjen sijasta oman osaamisen ja persoonallisuuden kehittämiseen. Bill Murray vapautui siis ajasta mutta ei paikasta. O nko koulutusteollisuudessa keksitty viisastenkivi, joka mahdollistaa molemmat?

Aikaa ja tilaa voidaan lähestyä ainakin seuraavasta neljästä näkökulmasta:

1. Aika ja tila ovat fyysisiä ilmiöitä, mutta niiden fyysinen luonne on monella tavalla ongelmallinen. Tässä yhteydessä ei tähän puututa lähemmin, mutta olennaista on huomata, että ajalla ja tilalla on fyysinen ulottuvuus, mutta se ei ole ainoa.

2. Y ksilön havainnot ajasta ja tilasta ovat ainutkertaisia, joskin kulttuurin ja yhteiskunnan säätelemiä. Havaitsemiseen liittyy $\mathrm{mm}$. havaintopsykologiset ilmiöt sekä yksilön kokemukset.

3. Institutionalisoitunut aika ja paikka tarkoittaa erilaisin normein ja säädöksin säädeltyjä muotoja. Monet yhteiskunnan ylläpitämät pakkolaitokset (armeija, koulu, sairaala) ovat institutionalisoineet myös ajan ja tilan käytön (esimerkiksi työajat, oppivelvollisuus, koulurakennukset).

4. Aikaa ja tilaa koskevat kulttuuriset konventiot tarkoittavat tapoja ja olettamuksia siitä, miten on soveliasta käyttää aikaa ja paikkaa. Esimerkiksi mikä on sallittava aika myöhästyä tapaamisesta tai kuinka kauan 
voidaan seurustella menemättä naimisiin tai missä voidaan syödä tai harrastaa seksuaalista aktiviteettia. Nämähän ovat täysin kulttuurisidonnaisia määrittelyjä.

K un riippumattomuutta ajasta ja paikasta tarkastellaan em. ulottuvuuksia vasten, asia mutkistuu. Riippumattomuus tarkoittaa, että yksiIön olisi irtauduttava kulttuurisista konventioista ja institutionalisoituneista muodoista. Jonkin verran tästä on empiiristä aineistoa; esim. H ein-N iemisen (1995) tutkimissa etäluokkahuoneissa opiskelijat 'tekivät olonsa mukavaksi' nyyttikestien muodossa, kun opettajan ainoa linkki ryhmään oli A tlantin takaa kaiutinpuhelimen kautta. Päivälehdissä puolestaan arvuutellaan, mitä kaikkea peruskoululuokissa tapahtuu opettajien pakkolomien aikana.

O n tietysti huomattava, että kulttuuri ja instituutiot muuttuvat. A jatellaanpa institutionalisoitunutta koulutusta. K oulutus ja opiskelu on yleensä sidottu tiettyyn paikkaan ja aikaan. O lisiko mahdollista irtaantua näistä? A jatus tuntuu houkuttelevalta. A luksi on rajattava tarkastelu koskemaan aikuisten koulutusta, koska yleissivistävä koulutus on yhteiskunnallista reproduktiota, joten sitä lienee mahdotonta irrottaa ajasta ja paikasta (edes opettajien Iomautusten ajaksi...). Riippumatto muuteen liitetään yleensä selitys, että opiskella voi missä ja milloin vain. Paikan suhteen tämä on helppo päätelmä. Virtuaalinen opiskelu ei voi olla paikasta riippumatonta, koska siellä pitää olla tietokone ja yhteys tietoverkkoon. O piskelua harrastetaan yleensä jossain yhteiskunnan perusinstituutiossa: oppilaitoksissa, kotona tai työpaikalla. Esimerkiksi kirja on monella tavalla riippumattomampi ajasta ja paikasta kuin tietokone. Riippumattomuus ajasta on hiukan ongelmallisempi, koska virtuaalista opiskelua voi periaatteessa harrastaa koska vain. E räs rajoitus on yksilön ajankäyttöä säätelevät kulttuuriset konventiot ja instituutiot. 0 piskelun pitää siis tapahtua näiden ulkopuolella tai erikseen sovittuna näiden puitteissa.

A jan ja tilan sosiaalisessa tarkastelussa on vääjäämättä mukana valta. Ajan ja tilan hallitse- minen on keskeinen vallan muoto. $\mathrm{H}$ allitseminen ei kuitenkaan ole välttämättä suoraa. Ihmiset toimivat tiettyjen sääntöjen mukaan, vaikka heitä ei erikseen määrätä toimimaan tietyllä tavalla. Valta on sisäistettyä. A jasta ja paikasta riippumattomuus tarkoittaa samalla riippumattomuutta vallasta. Tämä tuskin on mahdollista. Tietoverkkojen käytössä toteutuu foucaultlainen panoptinen valta, joskaan ei aivan puhtaassa muodossa, koska käyttäjiä ei välttämättä valvota jatkuvasti. Tietoverkkojen ja sähköpostin käyttö ovat kuitenkin saaneet panoptisen vallan muotoja (Zuboff 1990), joten opintojen suorittaminen ja verkossa olo voidaan nähdä valvonnaksi. Panoptisen vallan toimivuutta tietoverkoissa on epäilty ja tilalle on ehdotettu Baumanin esittämää viettelevän vallan periaatetta (Suoranta 1997, 252). Tärkeä havainto on, että tietoverkot liittyvät yhteiskunnalliseen vallankäyttöön.

Tärkeä havainto on myös se, että teknologialla on materiaalinen ja sosiaalinen aspekti (Sahay 1997, 235). O petusteknologian materiaalinen aspekti suo vapauksia tilan ja ajan suhteen, mutta sosiaalinen aspekti määrää paljolti sitä, miten teknologiaa käytetään. A jan ja paikan luonne liittyy hyvin paljon sosiaaliseen aspektiin, koska aika ja paikka ovat sosiaalisessa kontekstissa konstruoituja ilmiöitä (mt.). E i siis ole olemassa kaikille yhtenäistä ajasta ja paikasta riippumatonta opetusteknologiaa, vaan yksilöiden ja organisaatioiden tulkinnat ja jäsennykset ajan ja paikan merkityksistä vaihtelevat.

Johtopäätöksenä voi todeta, että uusien oppimisympäristöjen riippumattomuus ajasta ja paikasta tarkoittaa sitä, että opiskelu voi siirtyä uusiin ajankohtiin ja paikkoihin sekä sitä että aikaan ja paikkaan liittyvät tulkinnat ja merkitykset voivat muuttua. Riippumatonta ajasta ja paikasta opiskelu ei kuitenkaan ole. Vaikuttaisi siltä, että ajasta ja paikasta vapautuminen on varsin koulutusorganisaatiokeskeinen argumentti. O piskelija (ja opettaja) vapautuu oppilaitoksen luokkahuoneesta ja ehkä luentoajoista, mutta vain siirtääkseen oppimistilalle ja ajalle annetun merkityksen ja siihen liittyvän orjuuden johonkin toiseen aikaan ja fyysiseen 
tilaan (olo- tai makuuhuoneeseen, atk-luokkaan, videoneuvottelustudioon).

\section{Oppimisen konstruktiivisuus}

Uusien oppimisympäristöjen perusteluissa mainitaan lähes poikkeuksetta konstruktiivinen oppimiskäsitys. Tämä onkin järkevää, koska kognitiivinen (tai sen löperömpi ja muodikas konstruktivistinen versio) oppimisteoria on yksi harvoista kasvatustieteellisistä toimivista ja oikealta vaikuttavista teorioista. Siitäkin tosin kunnia on annettava oppimispsykologeille, ei kasvatustieteilijöille.

Vaarana konstruktivismissa on sen muodikkuus ja helposti omaksuttavat iskusanat, joilla on kätevää perustella lähes loputon kirjo erilaisia opetusjärjestelyjä ja määrärahahakemuksia. Suomessa on vain muutama (mm. Hakkarainen 1997) uusien oppimisympäristöjen kehittelijä, jolla oppimisteoria on hallussa ja todella oppimisympäristön rakentamisen tukena. E rityisesti - sinänsä tarpeellisen - teknisen taustan o maavilla on taipumus omaksua vain muodikkaat iskusanat kehitelmiensä käärepaperiksi, mutta todelliset kognitiiviset oppimista tukevat välineet loistavat poissaolollaan ja opetus toteutetaan yhtä tökerösti tai vielä tökerömmin kuin 'vanhoissa' luentosaleissa.

K onstruktivistinen oppimisteoria ei myöskään ole ainoa eikä aina välttämättä soveltuvin tapa lähestyä ja kehittää uusia oppimisympäristöjä. Suuri osa erityisesti aikuisten oppimisesta saattaa jäädä oppimisympäristöjen ulkopuolelle, jos niiden suunnittelussa korostetaan yksipuolisesti informaation ja oppisisältöjen roolia mm. vuorovaikutuksen ja kommunikatiivisuuden kustannuksella. K onstruktivismin kognitiivisen taustan hengessä uusissa oppimisympäristöissä korostetaan tietoa ja tietorakenteita keskeisenä oppimisen kohteena (Lehtinen 1997, 14; Pulkkinen 1997, 276). Lieneekö tämä seurausta tieto-sanan yleisyydestä (tietokone, tietoverkko, tietojärjestelmä jne.). Tietoverkkoihin liittyvässä keskustelussa on kuitenkin melko paljon kyseenalaistettu sitä, mitä tieto on ( $\mathrm{H}$ autamäki 1998, 60-62; K arvonen 171-204). 0 ppi- misen kohteena yleisesti pidetään informaatiota tai "jalostusarvoltaan" korkeampaa tietoa. Oppiminen on kuitenkin paljon muutakin kuin tiedon omaksumista ja konstruointia. E simerkiksi tietoverkon kautta avoimessa yliopistossa opis-kelleet kokivat opiskeltavan sisällön lisäksi opiskelun motiiviksi itse välineen eli Internetin tutuksi tulemisen (Koistinen 1998, 114). K yse ei ole pelkästään tiedon oppimisesta, vaan ihmisen persoonallisuuteen ja selviytymiskompetensseihin liittyvien strategioiden oppimisesta. $N$ iitä ei opita opiskelemalla, koska ne eivät ole tietoa. N e opitaan toimimalla, kohtaamalla toisia toimijoita.

\section{Itseohjautuvuus ja yhteistoiminnallisuus}

I tseohjautuvuuden diskurssi on yhteneväinen 'postmodernia' kulttuuriamme vahvasti leimaavan individualismieetoksen kanssa (kts. Manninen 1998a ja b). E i siis ole yllättävää, että uusia opiskeluympäristöjä perustellaan itseohjautu-vuudella.

Uudet oppimisympäristöt perustuvat paitsi itseohjautuvuuteen myös yhteistoiminnallisuuteen (Lehtinen 1997, 15-19; Tella 1997, 51-54). Tässä ilmenevä selkeä paradoksi (kuinka oppija voi samanaikaisesti olla itseohjautuva ja yhteistoiminnallinen) jää aina pohdiskelematta tai sitten sitä ei tiedosteta. Vaikka on yksinkertaistavaa asettaa itseohjautuvuutta ja yhteistoiminnallisuutta vastakkain tai toisiaan poissulkeviksi, niitä useimmiten käsitellään yhdessä, asiaa sen kummemmin problematisoimatta. A siasta puhumattomuus aiheuttaa sen, että ryhmädynaamisesti ja didaktisesti hedelmällinen jännite yksilön vapauden ja yhteistoiminnallisuuden välillä jää paikantamatta ja hyödyntämättä. Erinomaiset käsitteet 'cooperative freedom' (Paulsen 1992) ja 'interdependence' (A hteenmäki-Pelkonen 1994) sekä itseohjautuvuuden yhteisöllinen luonne (Pasanen 1998) tulevat harvoin jos koskaan eteen uusista oppimisympäristöistä puhuttaessa. Ryhmää ja yhteisöä voi pitää jopa perusedellytyksenä sille, että yksilö 
kehittyy kohti itseohjautuvuutta ja tietoisia valintoja (A hteenmäki-Pelkonen 1997).

\section{Joustavuus ja yksilöllisyys}

U usien oppimisympäristöjen perusteluissa vilisee myös joustavuuteen ja yksilöllisyyteen viittaavia termejä. Taustalla lienee ohjelmoituun opetukseen ja amerikkalaisten rakastamiin psykologisiin oppimistyyleihin pohjautuva utopia, että tietokoneeseen voidaan ohjelmoida valmiit polut jotka tarjotaan ja toteutuvat kunkin opiskelijan yksilöllisten tarpeiden ja oppimistyylien mukaan räätälöityinä.

K äytännössä yksilöllisyys ja joustavuus näyttäytyvät pahimmillaan linkkejä vilisevänä pullamössösivustona, josta kukin opiskelija voi eriytyä omista lähtökohdistaan seikkailemaan veppiin (käytännössä tosin useimmat päätyvät lopulta samoille pornosivuille). 'Parhaimmillaan' em. periaatteita yritetään operationalisoida tarjoamalla kaikille samat oppisisällöt ja kurssiaikataulut, jolloin vapaus rajautuu päätökseen aloittaakko sivujen selailu heti aamulla vai vasta iltapäivällä töiden jälkeen.

\section{Faktaa ja fiktiota, tekniikkaa ja teoriaa}

Tieteellisen ja yhteiskunnallisen argumentaation tulisi perustua tosiasioihin. $0 \mathrm{n}$ aiheellista kysyä, kuinka paljon uusien oppimisympäristöjen argumentaatio perustuu faktaan ja rationaalisuuteen? Todennäköisesti perustelut perustuvat sekä faktaan että fiktioon. K uten jo aiemmin havaitsimme, asioiden vastakkainasetteluun liittyy vaaroja. Tämä koskee myös faktan ja fiktion tarkastelua. Faktan rinnalla tarvitaan fiktiota. Fiktio auttaa luovuudessa, fiktion avulla irtaudumme totunnaisista ajatuksista ja tavoista. On kuitenkin kohtuullinen vaatimus, että uudet oppimisympäristöt perustellaan pääosin rationaalisella faktatiedolla. Tämä ei kuitenkaan ole itsestäänselvyys, sillä esimerkiksi tietoyhteiskuntaa koskeva puhe ei suinkaan ole kaikilta osin rationaalista (A ro 1997).
Uusien oppimisympäristöjen kohdalla on epäilty argumentaation pitävyyttä. Pantzar ja Väliharju $(1996,23)$ toteavat: "Rohkeasti yleistäen voi väittää, että avoimuuden luonnehdinta ja sovellukset ovat olleet pikemminkin normatiivisia ohjelmanjulistuksia kuin opetuksen ja opiskelun suunnittelun strategiaa tai teoreettisesti hyvin perusteltuja operaatioita, toimenpiteitä. Avointen oppimisympäristöjen tukeutuessa yhä enemmän kommunikaatio- ja informaatioteknologisiin ratkaisuihin saman teoriattomuuden riski on ilmeinen."

Uusien oppimisympäristöjen perustelut liittyvät usein tietotekniikan kehitykseen. Vaikuttaa siltä, että tietotekniikka kehittyy nopeammin kuin opiskelun tarpeet ja oppimisteoriat. Uusien oppimisympäristöjen kehittäminen on usein (mutta ei aina!) teknologiajohtoista. Tämä on tuttu ilmiö tietotekniikan soveltamisessa yleensäkin, esimerkiksi organisaatiot kehittyvät ja muuttuvat tietotekniikan ehdoilla (Zuboff 1990). Tekniikkakeskeisyys näkyy siinä, että tietoverkkoihin liittyvän pedagogisen ja didaktisen teorian kehittelyä pidetään tärkeänä, kuten seuraavista kommenteista ilmenee:

"Tuleraisuuden (verkko)pedagogikan onkin kyettävä yhdistämään tarkaituksenmkaisella tavalla koulun tavaittellisesti organisoidut oppimisympäristöt erilaisten mediaiden tarjoamiin mahddlisuuksiin. Tämä yhdistäminen è de helppoa, sillä mediciden ja tiđoverkkojen maailma on monessa surteessa täysin vastakkainen niille periaatteille jaille institutionaalinen koulutus on rakentunut." (Ledtinen 1997, 7)

"Tietoverkkgien käyttö osana koulun ope tusta vaatii untta pedagogista ajattelua ja soveltamista." (Levonen \& Tuononen 1998, 70).

K uitenkin pedagoginen ja didaktinen teoriankehittely ja tutkimus on laahannut tekniikan perässä. Ja vaikka relevanttia vanhempaakin teoriatietoa ja tutkimusta olisikin olemassa, se usein unohdetaan tai sitä ei tunneta. Esimerkiksi Aikuiskasvatuksen Oppiminen ja uusi tek- 
nologia -teemanumerossa oli vain kaksi eksplisiittisesti pedagogisia ja didaktisia kysy-myksiä pohtivaa artikkelia (Manninen \& Pesonen 1997; Pulkkinen 1997). Lisäksi opettajat ilmoittavat tarvitsevansa huomattavasti enemmän pedagogista koulutusta verrattuna tietotekniseen koulutukseen (Ilomäki ym. 1998, 96). M uuttuvatko oppimisen lait ja pedagogiset periaatteet tietoyhteiskunnan myötä jotenkin radikaalisti, vai ovatko opettajien ja kouluttajien didaktiset valmiudet ja ymmärrys olleet jo jälkiteollisessa yhteiskunnassa retuperällä, mutta sitä ei ole vain huomattu toimittaessa suljetuissa luokkahuoneissa?

Tietotekniikan lisäksi uusia oppimisympäristöjä perustellaan yhteiskunnan muutoksella. Esimerkkinä tästä on Marttusen $(1997,284)$ toteamus, että "Verkostoituminen erityisesti sähköpostin avulla kontakteja luomalla ja ylläpitämällä yleistyy koko ajan“. Sitaatti ei ole M arttusen artikkelin kannalta olennainen, mutta kuvastaa vetoamista yhteiskunnan yleiseen muutokseen. On common sense tietoa, että verkostoituminen sähköpostin avulla yleistyy, eikä sitä tarvitse perustella. Esille kuitenkin nousee kysymys, että onko näin? Luodaanko kontakteja sähköpostilla vai ylläpidetäänkö aiemmin luotuja kontakteja sähköpostilla? Marttusen artikkelin sitaatti on detalji, mutta se toimii oivana esimerkkinä, kuinka asiat perustellaan common sensenä. $\mathrm{N}$ iitä ei tarvitse perustella ja sanoa, koska 'on sanomattakin selvää' (vrt. Suoninen 1997, 29). Aro (1997) on osoittanut, kuinka yhteiskunnallista muutosta perustellaan suurilla luvuilla ja metaforilla, mutta muutoksen todellinen luonne jää hämärän peittoon. K iinnostava yksityiskohta Aron (mt.) analyysissä on tietoyhteiskuntapuheen paradoksi: kaikki muu muuttuu, paitsi talous. Olisiko uusiin oppimisympäristöihin liittyvässä puheessa sama ilmiö: kaikki muuttuu, paitsi oppimisen tärkeys. 0 ppimisen tärkeys perustellaan usein juuri tietoyhteiskunnalla (esim. Lehtinen 1997). Tässä on nähtävissä myös tietoyhteiskunnan ja oppimisen "salaliitto", tietoyhteiskunta edellyttää oppimista ja oppiminen on tietoyhteiskunnan keskeinen ominaisuus. Teknologisesta painotuksesta huolimatta yhteistä uusien oppimisympäris- töjen perusteluille näyttää olevan oppimisen tärkeys.

\section{Lopuksi: Pakoa vapaudesta}

Monet edellä käsitellyt teemat (aika, tila, tieto, itseohjautuvuus ja yhteistoiminnallisuus, joustavuus, yksilöllisyys) liittyvät vapauteen. Vapauden teema on ongelmallinen. Vapaus on useimpien inmisten ja yhteiskuntien tavoitteena, mutta on suorastaa traagista, kuinka vapautta ei osata käyttää. Pakoa vapaudesta kuvasi Erich Fromm jo 1940-Iuvulla (Fromm 1941). Vaikka inmisillä olisi mahdollisuus olla vapaita, toimia itseohjautuvasti omien motiivien pohjalta, he eivät sitä välttämättä tee. I hmiset haluavat sitoutua johonkin: sosiaaliseen yhteisöön, toisiin inmisiin ja aatteeseen. O n oma vaaransa, että uusien oppimisympäristöjen suomaa vapautta ei ehkä osatakaan käyttää. Tämä koskee yhtä hyvin oppijoita kuin opettajia ja suunnittelijoita. M illaista vapautta edustaa esimerkiksi seuraava opiskelumalli: "O ppija asetetaan keskeiseen ja aktiiviseen rooliin reaalimaailmaa peilaavan huonosti määritellyn ongelman eteen (H atakka 1998, 86)". O piskelija on aktiivinen, mutta hänet asetetaan tiettyyn tilanteeseen. E päselväksi jää kuka hänet asettaa, ilmeisimmin opettaja.

E dellä mainittu lainaus ja koko artikkeli herättävät ajatuksia siitä, millaista uusien oppimisympäristöjen suoma vapaus on. O nko vapautta olla riippuvainen tietokoneesta? Mistä ja mihin se on vapautta?

\section{Lähteet}

AHTEEN M ̈̈K I-PELK ONEN, L. (1994) From selfdirectedness to interdependence? An analysis of Mezirow's conceptualization of self-directed learning. In: Tösse, S. \& Wahlgren, B. \& Manninen, J. \& Klasson, M. (1994) (eds.) Socal Change and Adult Education Research - Adult Education Research in Nordic Countries 1992/ 93. Trondheim: Nork Voksenpedagogisk Institut. 
A H TEEN MÄK I-PELKONEN , L. (1997) Kriittinen näkemys itseohjautumudesta. Systemaattinen analyysi Jack Mezirowin itseohjautuvuuskäsityksistä. Helsingin yliopiston kasvatustieteen laitoksen tutkimuksia 157. Helsinki: Hakapaino $0 \mathrm{y}$.

ARO, J. (1997) Miten tietoyhtéskunnasta puhutaan? E sitelmä sosiologipäivillä 21.3.1997 H elsingissä. http:/ / www.uta.fi/ ssjaar/ sesitelm.htm.

BILLIG, M. (1996): Arguing and Thinking A Rhetorical A pproach to Social Psychology. 2nd ed. Cambridge: Cambridge University Press.

FROMM , E. (1941/1969) Escape from Freedom $\mathrm{N}$ ew York: Avon Books.

HAK K ARA INEN, K. (1997) Verkostopohjaiset oppimisympäristöt ja kognitio. Teoksessa Lehtinen, E. (toim.) Verkkopedagogikka. Helsinki: E dita, 60-84.

HATAKKA, O. (1998) Kollaboratiivinen verkkoperustainen oppimisympäristö REM. Interaktiivinen teknologia koulutuksessa -konferenssi 17.18.4.1998 Aulanko, s. 85-88.

H AUTAMÄKI, A. (1998) Tieđtekniikka merkitysten välittäjänä. Informaatio vai tieto? Interaktiivinen teknologia koulutuksessa -konferenssi 17.-18.4.1998 Aulanko, s. 60-62.

H E IN - N IE M I N E N , I. (1995) V irtuaaliluokan ul ottumuksia: tapaustutkimus kansainvälisestä eäopetuksesta. Lisensiaatintutkimus. H elsingin yliopisto, kasvatustieteen laitos.

I L O MÄK I, L., H alinen, I., H akkarainen, K. \& Lipponen, L. (1998) Pedagoginen ajattelu ja tiđotekninen osaaminen. Tutkimus helsinkiläisten opettajien muuttuvasta opettamisen asiantuntijuudesta. Interaktiivinen teknologia koulutuksessa -konferenssi 17.-18.4.1998 A ulanko, s. 9697.

K ARVONEN, E. (1997) K ohti relationaalista tietokäsitystä. Teoksessa Stachon, K. (toim.): Näkökulmia tiđgyhteskuntaan. Tampere: G audeamus.

K O IST IN E N, M. (1998) Kokemuksia J dhdatus viestintään -verkkokurssista. Interaktiivinen teknologia koulutuksessa -konferenssi 17.-18.4.1998 A ulanko, s. 114.

K N O WLES, M . (1970) The modern practice of adult education: from pedagggy to andragogy. N ew York: Associated Press.

LEHTINEN, E. (1997) Tietoyhteiskunnan haasteet ja mahdollisuudet oppimiselle. Teoksessa Lehtinen, E. (toim.) Verkkopedagogikka. Helsinki: E dita, 12-40.

LEVONEN, J. \& Tuononen, K. (1998) Tietoverkot peruskoulun oppilaiden välineenä: Tapauskuvaus
H yperNewsin ja Linuxin käytöstä koulussa. Interaktiivinen teknologia koulutuksessa -konferenssi 17.-18.4.1998 Aulanko, s. 68-70.

MAN N INEN , J , (1998a) Labour market training strategies in a late modern society. In: Walther, A. \& Stauber, B. (eds.) Lifelong learning in Europe / L ebenslanges lernen in Europa, Vol. 1, Options for the integration of living, learning and working. Tubingen: Neulig Verlag.

MAN N INEN, J. (1998b) (toim.) Aikuiskoulutus modarnin murroksessa. Näkökulmia työllistymistä edistävän koulutuksen ja ohjauksen merkityksiin ja vaikuttavuuteen. Helsingin yliopisto, kasvatustieteen laitos, tutkimuksia 158.

MANNINEN, J. \& Pesonen, S. (1997) Uudet oppimisympäristöt. A ikuiskasvatus 4, 267-274.

MARTTUNEN, M. (1997) Sähköpostiopetuksella perustelevaan keskusteluun. Aikuiskasvatus 4, 283-290.

PANTZAR, E \& \& Väliharju, T. (1996) Kohti virtuaalisia oppimisympäristöä. A mmatti-instituutti. Julkaisu 1/ 96.

PASAN NE, H. (1998) Refleksiivisen itseohjautuvuuskäsityksen hahmotusta. Teoksessa: Manninen, J. 1998 (toim.) Aikuiskoulutus modernin murroksessa. N äkökulmia työllistymistä edistävän koulutuksen ja ohjauksen merkityksiin ja vaikuttavuuteen. Helsingin yliopiston kasvatustieteen laitoksen tutkimuksia 158.

PAULSEN, M. (1992) The hexagon of cooperative freedom. Deosnens 3, 2.

PULKKINEN, J. (1997) Avoimen opiskeluympäristöjen toiminnallisia lähtökohtia. Aikuiskasvatus 4, 275-282.

SAHAY, S. (1997) Implementation of Information Technology: A Time-Space Perspective. Organization Studies 18/2, 229-260.

SU O N INEN, E. (1997) Miten tutkia moniäänistä itmistä? Tampere: Tampereen yliopisto.

SU ORANTA, J. (1997) Mediakulttuurin ja oppimisteknologian paradokseja. Aikuiskasvatus 4, 249257.

TELLA， S. (1997) Verkostuva viestintä- ja tiedonhallintaympäristö opiskelun tukena. Teoksessa Lehtinen, E. (toim.) Verkkopedagogikka. H elsinki: E dita.

ZUBO FF, S. (1990) V iisaan koneen aikausi. H elsinki: Otava 